\title{
Synthesis, Crystal Structures, and Antimicrobial Activity of Zinc(II) and Manganese(II) Complexes Derived from $N^{\prime}$-(1-(Pyridin-2-yl)Ethylidene)Isonicotinohydrazide
}

\author{
Ling-Wei Xue, ${ }^{\star}$ Hui-Jie Zhang and Pan-Pan Wang \\ College of Chemistry and Chemical Engineering, Pingdingshan University, Pingdingshan Henan 467000, P.R. China \\ *Corresponding author: E-mail: pdsuchemistry@163.com
}

Received: $10-08-2018$

\begin{abstract}
Two mononuclear zinc(II) and manganese(II) compounds, $\left[\mathrm{ZnL}_{2}\right](\mathbf{1})$ and $[\mathrm{MnL}(\mathrm{HL})] \mathrm{ClO}_{4}(\mathbf{2})$, where $\mathrm{L}$ is the monoanionic form of $N^{\prime}$-(1-(pyridin-2-yl)ethylidene)isonicotinohydrazide (HL), and $\mathrm{HL}$ is the zwitterionic form of $\mathrm{HL}$, have been prepared and characterized by elemental analyses, IR and UV-Vis spectroscopy, and single-crystal X-ray crystallographic determination. Compound $\mathbf{1}$ contains a neutral $\left[\mathrm{ZnL}_{2}\right]$ complex molecule. Compound $\mathbf{2}$ contains a $[\mathrm{MnL}(\mathrm{HL})]^{+}$ complex cation and one perchlorate anion. The metal atoms in the complexes are in octahedral coordination. The hydrazone ligands coordinate to the metal atoms through the pyridine $\mathrm{N}$, imine $\mathrm{N}$, and enolate $\mathrm{O}$ atoms. The compounds were investigated for their antimicrobial activity against Staphylococcus aureus, Escherichia coli, and Candida albicans.
\end{abstract}

Keywords: Hydrazone, Zinc complex, Manganese complex, Crystal structure, Antimicrobial activity

\section{Introduction}

Schiff bases bearing characteristic $\mathrm{C}=\mathrm{N}$ bonds are a kind of versatile ligands in coordination chemistry. ${ }^{1}$ In recent years, metal complexes of Schiff bases have attracted considerable attention due to their interesting biological activity, such as antifungal, antibacterial and antitumor. ${ }^{2}$ Schiff base complexes derived from salicylaldehyde and its derivatives with primary amines, bearing the $\mathrm{N}_{2} \mathrm{O}, \mathrm{N}_{2} \mathrm{~S}$, $\mathrm{NO}_{2}$ or NSO donor sets, have particular biological activities. ${ }^{3}$ Hydrazone is a kind of special Schiff base compound, which possess interesting biological activities. ${ }^{4}$ Metal complexes usually show stronger biological activities than the hydrazone ligands. ${ }^{5}$ Chang and coworkers have reported that some transition metal complexes derived from $N^{\prime}$ (1-(pyridin-2-yl)ethylidene)isonicotinohydrazide (HL; Scheme 1) have interesting antitumor and antioxidant activities. ${ }^{6}$ However, no report on the antimicrobial activity of complexes derived from HL has been reported so far. As an extension of our work on Schiff base complexes, ${ }^{7}$ a new<smiles>C/C(=N\NC(=O)c1ccncc1)c1ccccn1</smiles>

Scheme 1. The ligand HL
zinc(II) compound, [ $\left.\mathrm{ZnL}_{2}\right]$ (1), and a new manganese(II) compound, $[\mathrm{MnL}(\mathrm{HL})] \mathrm{ClO}_{4}(2)$, are reported.

\section{Experimental}

\section{1. Material and Methods}

2-Acetylpyridine and pyridine-4-carbohydrazide were purchased from Fluka. Other reagents and solvents were analytical grade and used without further purification. Elemental $(\mathrm{C}, \mathrm{H}$, and $\mathrm{N})$ analyses were made on a Perkin-Elmer Model 240B automatic analyzer. Infrared (IR) spectra were recorded on an IR-408 Shimadzu 568 spectrophotometer. UV-Vis spectra were recorded on a Lambda 35 spectrometer. X-ray diffraction was carried out on a Bruker SMART 1000 CCD area diffractometer. The ligand HL was prepared according to the literature method. ${ }^{8}$

Caution! Perchlorate salts are potentially explosive. Only a small amount of material should be prepared, and they should be handled with great care.

\section{2. Synthesis of Compound 1}

The hydrazone ( $48.0 \mathrm{mg}, 0.20 \mathrm{mmol}$ ) was dissolved by methanol $(10 \mathrm{~mL})$ and then a methanol solution $(10 \mathrm{~mL})$ of $\mathrm{Zn}\left(\mathrm{ClO}_{4}\right) 6 \mathrm{H}_{2} \mathrm{O}(37.2 \mathrm{mg}, 0.10 \mathrm{mmol})$ was added with stir- 
ring. The mixture was stirred for $1 \mathrm{~h}$ at ambient temperature to give a colorless solution. Colorless block-shaped single crystals suitable for X-ray diffraction were formed by slow evaporation of the solution in air for several days. The yield is $45 \%$ (based on $\mathrm{Zn})$. IR data $\left(\mathrm{KBr}, \mathrm{cm}^{-1}\right): 1595(\mathrm{C}=\mathrm{N})$,

Table 1. Crystallographic data and refinement parameters for complexes $\mathbf{1}$ and $\mathbf{2}$

\begin{tabular}{|c|c|c|}
\hline Parameters & 1 & 2 \\
\hline Habit, color & Block, colorless & Block, brown \\
\hline Molecular formula & $\mathrm{C}_{26} \mathrm{H}_{22} \mathrm{~N}_{8} \mathrm{O}_{2} \mathrm{Zn}$ & $\begin{array}{l}\mathrm{C}_{26} \mathrm{H}_{23} \mathrm{ClMn}- \\
\mathrm{N}_{8} \mathrm{O}_{6}\end{array}$ \\
\hline Formula weight & 543.89 & 633.91 \\
\hline Crystal system & Orthorhombic & Monoclinic \\
\hline Space group & $A b a 2$ & $P 2_{1} / n$ \\
\hline \multicolumn{3}{|l|}{ Unit cell dimensions: } \\
\hline$a, \AA$ & $12.363(2)$ & $11.755(2)$ \\
\hline$b, \AA$ & $20.251(2)$ & $9.437(2)$ \\
\hline$c, \AA$ & $9.595(2)$ & $26.198(2)$ \\
\hline$\alpha,{ }^{\circ}$ & 90 & 90 \\
\hline$\beta,{ }^{\circ}$ & 90 & $98.197(2)$ \\
\hline$\gamma,{ }^{o}$ & 90 & 90 \\
\hline$V, \AA^{3}$ & $2402.2(7)$ & $2876.5(8)$ \\
\hline$Z$ & 4 & 4 \\
\hline$\rho_{\text {calcd }}, \mathrm{g} \mathrm{cm}^{-3}$ & 1.504 & 1.464 \\
\hline$F(000)$ & 1120 & 1300 \\
\hline Absorption coefficient, $\mathrm{mm}^{-1}$ & 1.065 & 0.607 \\
\hline Reflections collected & 6959 & 16410 \\
\hline Independent reflections & 1732 & 5322 \\
\hline Data/parameters & $1353 / 169$ & $3869 / 381$ \\
\hline Restraints & 1 & 0 \\
\hline$R_{1}, w R_{2}[I>2 \sigma(I)]$ & $0.0333,0.0634$ & $0.0879,0.2408$ \\
\hline$R_{1}, w R_{2}$ (all data) & $0.0538,0.0718$ & $0.1133,0.2583$ \\
\hline Goodness-of-fit on $F^{2}$ & 1.020 & 1.070 \\
\hline
\end{tabular}

1498, 1451, 1363, 1160, 1072, 947, 854, 543, 522. UV-vis data in methanol $\left[\lambda_{\max }(\mathrm{nm}), \varepsilon\left(\mathrm{L} \mathrm{mol}^{-1} \mathrm{~cm}^{-1}\right)\right]: 277,6450$; 362, 15510. Anal. Calcd. (\%) for $\mathrm{C}_{26} \mathrm{H}_{22} \mathrm{~N}_{8} \mathrm{O}_{2} \mathrm{Zn}$ : C, 57.42; H, 4.08; N, 20.60. Found (\%): C, 57.61; H, 4.17; N, 20.45.

\section{3. Synthesis of Compound 2}

The hydrazone $(48.0 \mathrm{mg}, 0.20 \mathrm{mmol})$ was dissolved by methanol $(10 \mathrm{~mL})$ and then a methanol solution $(10$ $\mathrm{mL})$ of $\mathrm{Mn}\left(\mathrm{ClO}_{4}\right)_{2} 6 \mathrm{H}_{2} \mathrm{O}(36.2 \mathrm{mg}, 0.10 \mathrm{mmol})$ was added with stirring. The mixture was stirred for $1 \mathrm{~h}$ at ambient temperature to give a brown solution. Brown block-shaped single crystals suitable for X-ray diffraction were formed by slow evaporation of the solution in air for several days. The yield is $33 \%$ (based on $\mathrm{Mn}$ ). IR data $\left(\mathrm{KBr}, \mathrm{cm}^{-1}\right): 1596$ $(\mathrm{C}=\mathrm{N}), 1499,1450,1365,1160,1079\left(\mathrm{ClO}_{4}\right), 945,855,756$, $696,622,546,518$. UV-vis data in methanol $\left[\lambda_{\max }(\mathrm{nm}), \varepsilon\right.$ (L mol-1 $\mathrm{cm}^{-1}$ )]: 271, 7270; 366, 16480. Anal. Calcd. (\%) for $\mathrm{C}_{26} \mathrm{H}_{22} \mathrm{ClMnN}_{8} \mathrm{O}_{6}$ : C, 49.34; H, 3.50; N, 17.70. Found (\%): C, 49.16; H, 3.62; N, 17.83 .

\section{4. X-ray Structure Determination}

Data were collected from selected crystals mounted on glass fibres. The data were collected with $\mathrm{Mo} K_{\alpha}$ radiation $(0.71073 \AA)$ at $298(2) \mathrm{K}$ with a Bruker SMART 1000 CCD area diffractometer. The data for the two complexes were processed with $\mathrm{SAINT}^{9}$ and corrected for absorption using SADABS. ${ }^{10}$ Multi-scan absorption corrections were applied with $\psi$-scans. ${ }^{11}$ The structures were solved by direct methods using the program SHELXS-97 and were refined by full-matrix least-squares techniques on $F^{2}$ using anisotropic displacement parameters. ${ }^{12}$ All hydrogen atoms were placed at the calculated positions. Idealized $\mathrm{H}$ atoms

Table 2. Selected bond lengths $(\AA)$ and bond angles $\left(^{\circ}\right)$ for complexes $\mathbf{1}$ and $\mathbf{2}$

\begin{tabular}{lrlr}
\hline $\mathbf{1}$ & & & \\
$\mathrm{Zn}(1)-\mathrm{N}(3)$ & $2.069(3)$ & $\mathrm{Zn}(1)-\mathrm{O}(1)$ & $2.149(3)$ \\
$\mathrm{Zn}(1)-\mathrm{N}(4)$ & $2.193(4)$ & & \\
$\mathrm{N}(3)-\mathrm{Zn}(1)-\mathrm{N}(3 \mathrm{~A})$ & $173.3(3)$ & $\mathrm{N}(3)-\mathrm{Zn}(1)-\mathrm{O}(1 \mathrm{~A})$ & $101.34(13)$ \\
$\mathrm{N}(3)-\mathrm{Zn}(1)-\mathrm{O}(1)$ & $74.22(13)$ & $\mathrm{O}(1)-\mathrm{Zn}(1)-\mathrm{O}(1 \mathrm{~A})$ & $100.30(17)$ \\
$\mathrm{N}(3)-\mathrm{Zn}(1)-\mathrm{N}(4)$ & $75.14(14)$ & $\mathrm{N}(3)-\mathrm{Zn}(1)-\mathrm{N}(4 \mathrm{~A})$ & $109.70(15)$ \\
$\mathrm{O}(1)-\mathrm{Zn}(1)-\mathrm{N}(4 \mathrm{~A})$ & $91.47(13)$ & $\mathrm{O}(1)-\mathrm{Zn}(1)-\mathrm{N}(4)$ & $148.77(11)$ \\
$\mathrm{N}(4)-\mathrm{Zn}(1)-\mathrm{N}(4 \mathrm{~A})$ & $93.19(19)$ & & \\
\hline $\mathbf{2}$ & & & \\
$\mathrm{Mn}(1)-\mathrm{O}(1)$ & $2.144(4)$ & $\mathrm{Mn}(1)-\mathrm{O}(2)$ & $2.151(4)$ \\
$\mathrm{Mn}(1)-\mathrm{N}(7)$ & $2.191(4)$ & $\mathrm{Mn}(1)-\mathrm{N}(3)$ & $2.193(4)$ \\
$\mathrm{Mn}(1)-\mathrm{N}(4)$ & $2.314(5)$ & $\mathrm{Mn}(1)-\mathrm{N}(8)$ & $2.326(4)$ \\
$\mathrm{O}(1)-\mathrm{Mn}(1)-\mathrm{O}(2)$ & $107.34(16)$ & $\mathrm{O}(1)-\mathrm{Mn}(1)-\mathrm{N}(7)$ & $12.05(15)$ \\
$\mathrm{O}(2)-\mathrm{Mn}(1)-\mathrm{N}(7)$ & $72.27(15)$ & $\mathrm{O}(1)-\mathrm{Mn}(1)-\mathrm{N}(3)$ & $72.01(14)$ \\
$\mathrm{O}(2)-\mathrm{Mn}(1)-\mathrm{N}(3)$ & $125.51(15)$ & $\mathrm{N}(7)-\mathrm{Mn}(1)-\mathrm{N}(3)$ & $155.58(17)$ \\
$\mathrm{O}(1)-\mathrm{Mn}(1)-\mathrm{N}(4)$ & $142.00(15)$ & $\mathrm{O}(2)-\mathrm{Mn}(1)-\mathrm{N}(4)$ & $90.07(16)$ \\
$\mathrm{N}(7)-\mathrm{Mn}(1)-\mathrm{N}(4)$ & $95.15(16)$ & $\mathrm{N}(3)-\mathrm{Mn}(1)-\mathrm{N}(4)$ & $70.41(15)$ \\
$\mathrm{O}(1)-\mathrm{Mn}(1)-\mathrm{N}(8)$ & $90.69(16)$ & $\mathrm{O}(2)-\mathrm{Mn}(1)-\mathrm{N}(8)$ & $142.58(14)$ \\
$\mathrm{N}(7)-\mathrm{Mn}(1)-\mathrm{N}(8)$ & $70.38(15)$ & $\mathrm{N}(3)-\mathrm{Mn}(1)-\mathrm{N}(8)$ & $90.90(15)$ \\
$\mathrm{N}(4)-\mathrm{Mn}(1)-\mathrm{N}(8)$ & $95.35(16)$ & & \\
\hline
\end{tabular}

Symmetry code for A: $-x,-y, z$. 
were refined with isotropic displacement parameters set to 1.2 ( 1.5 for methyl groups) times the equivalent isotropic $U$ values of the parent atoms. The large average $U_{\text {eq }}$ of residue including $\mathrm{Cl} 1$ (0.335) in complex is caused by the disorder of the perchlorate anion. The crystallographic data for the complexes are listed in Table 1, selected bond lengths and bond angles for compounds $\mathbf{1}$ and $\mathbf{2}$ are given in Table 2 .

\section{5. Antimicrobial Assay}

Qualitative determination of antimicrobial activity was done using the disk diffusion method as described in the literature. ${ }^{13}$ Suspensions in sterile peptone water from $24-\mathrm{h}$ cultures of microorganisms were adjusted to $0.5 \mathrm{McF}$ arland. Muller-Hinton Petri dishes of $90 \mathrm{~mm}$ were inoculated using these suspensions. Paper disks ( $6 \mathrm{~mm}$ in diameter) containing $10 \mu \mathrm{L}$ of the substance to be tested (at a concentration of $2048 \mu \mathrm{g} / \mathrm{mL}$ in DMSO) were placed in a circular pattern in each inoculated plate. Incubation of the plates was done at $37^{\circ} \mathrm{C}$ for $18-24 \mathrm{~h}$. Reading of the results was done by measuring the diameters of the inhibition zones generated by the test substance. Tetracycline was used as a reference substance. Determination of MIC was done using the serial dilutions in liquid broth method. The materials used were 96-well plates, suspensions of microorganism (0.5 McFarland), Muller-Hinton broth (Merck) and stock solutions of each substance to be tested $(2048 \mu \mathrm{g} / \mathrm{mL}$ in DMSO). The following concentrations of the substances to be tested were obtained in the 96 -well plates: $1024,512,256,128,64,32$, $16,8,4$ and $2 \mu \mathrm{g} / \mathrm{mL}$. After incubation at $37^{\circ} \mathrm{C}$ for $18-24 \mathrm{~h}$, the MIC for each tested substance was determined by microscopic observation of microbial growth. It corresponds to the well with the lowest concentration of the tested substance where microbial growth was clearly inhibited.

\section{Results and Discussion}

\section{1. Chemistry}

The hydrazone compound HL was prepared by the condensation of equimolar quantities of 2-acetylpyridine with pyridine-4-carbohydrazide in methanol at ambient temperature. The hydrazone compound prepared in this way was formed in nearly quantitative yield and of high purity. The compounds $\mathbf{1}$ and $\mathbf{2}$ were readily synthesized by reaction of the hydrazone compound HL with zinc perchlorate and manganese perchlorate in methanol at ambient temperature. All the compounds are very stable at room temperature in the solid state, and soluble in common organic solvents, such as methanol, ethanol, and acetonitrile. The results of the elemental analyses are in accord with the composition suggested for the hydrazone and the complexes.

\section{2. IR and UV-Vis Spectra}

The typical band indicative of the azomethine group in the ligand of the complexes was observed at $1595 \mathrm{~cm}^{-1}$ for compound 1 and $1596 \mathrm{~cm}^{-1}$ for compound 2 . The strong absorption at $1079 \mathrm{~cm}^{-1}$ in the spectrum of compound 2 is assigned to the stretching vibration of the perchlorate anion. UV-visible spectra of HL and the complexes were carried out in methanol. In the hydrazone, the band at 345 $\mathrm{nm}$ is attributed to the azomethine chromophore $\pi-\pi^{*}$ transition. The band at higher energy $(265 \mathrm{~nm})$ is associated with the benzene $\pi-\pi^{*}$ transition. In the spectra of the complexes, however, the azomethine chromophore $\pi-\pi^{*}$ transition is shifted to $362-366 \mathrm{~nm}$, indicating that the imino nitrogen is involved in coordination to the metal ion. The absorption frequencies ascribed to the benzene $\pi-\pi^{*}$ transition (271-277 $\mathrm{nm}$ ) are slightly changed.

\section{3. Structure Description of Compound 1}

The molecular structure of compound $\mathbf{1}$ is shown in Fig. 1. Selected bond distances and angles are listed in Table 2 . The $\mathrm{Zn}$ atom is coordinated by two pyridine N, two imine $\mathrm{N}$, and two enolate $\mathrm{O}$ atoms from two deprotonated forms of hydrazone ligands, forming an octahedral geometry. The hydrazone acts as a tridentate ligand, forming two five-membered chelate rings with the $\mathrm{Zn}$ atom. The bond distances subtended at the $\mathrm{Zn}$ atom are comparable to those observed in the similar zinc(II) complexes with Schiff bases. ${ }^{14}$ The cis and trans coordinate bond angles are

Table 3 Distances $(\AA)$ and angles $\left({ }^{\circ}\right)$ involving hydrogen bonding of the complexes

\begin{tabular}{lcccc}
\hline$D-\mathbf{H} \cdots A$ & $\mathbf{d}(D-\mathbf{H})$ & $\mathbf{d}(\mathbf{H} \cdots A)$ & $\mathbf{d}(D \cdots A)$ & Angle $(D-\mathbf{H} \cdots A)$ \\
\hline $\mathbf{1}$ & & & & \\
$\mathrm{C}(9)-\mathrm{H}(9) \cdots \mathrm{O}(1)^{\# 1}$ & 0.93 & $2.36(5)$ & $3.180(5)$ & $148(6)$ \\
$\mathrm{C}(10)-\mathrm{H}(10) \cdots \mathrm{N}(1)^{\# 2}$ & 0.93 & $2.54(5)$ & $3.455(5)$ & $170(6)$ \\
$\mathrm{C}(13)-\mathrm{H}(13 \mathrm{~A}) \cdots \mathrm{N}(2)$ & 0.96 & $2.43(5)$ & $2.811(5)$ & $103(6)$ \\
\hline $\mathbf{2}$ & & & & \\
$\mathrm{N}(1)-\mathrm{H}(1) \cdots \mathrm{N}(5)^{\# 3}$ & 0.93 & $2.39(3)$ & $3.284(4)$ & $161(7)$ \\
$\mathrm{C}(10)-\mathrm{H}(10) \cdots \mathrm{O}(5)^{\# 4}$ & 0.93 & $2.39(3)$ & $3.284(4)$ & $161(7)$ \\
$\mathrm{C}(13)-\mathrm{H}(13 \mathrm{C}) \cdots \mathrm{N}(2)$ & 0.96 & $2.40(3)$ & $2.778(4)$ & $103(5)$ \\
$\mathrm{C}(23)-\mathrm{H}(23) \cdots \mathrm{O}(6)^{\# 5}$ & 0.93 & $2.48(4)$ & $3.258(5)$ & $142(6)$ \\
$\mathrm{C}(26)-\mathrm{H}(26 \mathrm{~A}) \cdots \mathrm{N}(6)$ & 0.96 & $2.37(3)$ & $2.788(4)$ & $106(5)$ \\
\hline
\end{tabular}

Symmetry codes: $\# 1: 1 / 2+x,-y,-1 / 2+z ; \# 2: 1 / 2-x,-1 / 2+y,-1+z ; \# 3: 1 / 2+x,-1 / 2-y,-1 / 2+z ; \# 4: 1 / 2-x$,

$1 / 2+y, 1 / 2-z ; \# 5:-x, 1-y,-z$. 


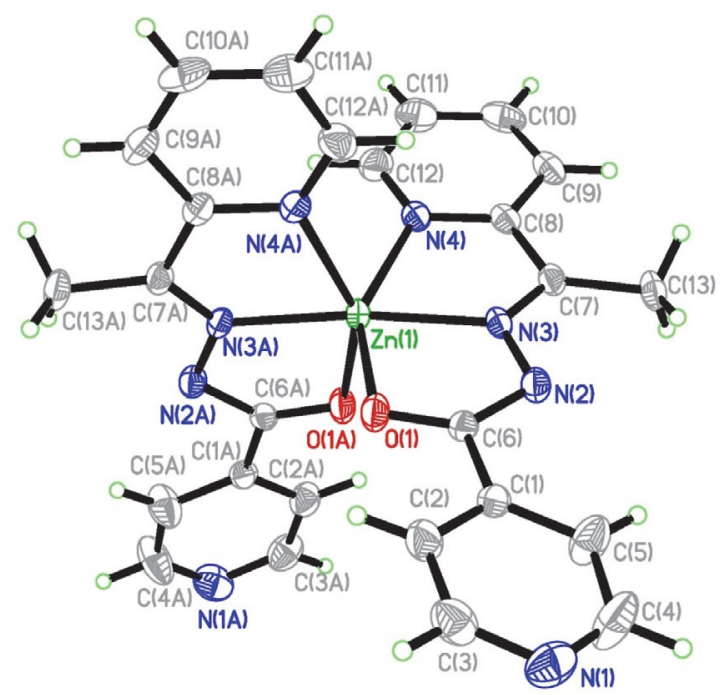

Fig. 1. Perspective view of complex 1 with $30 \%$ probability thermal ellipsoids. Atoms labeled with the suffix A are related to the symmetry operation $-x,-y, z$.

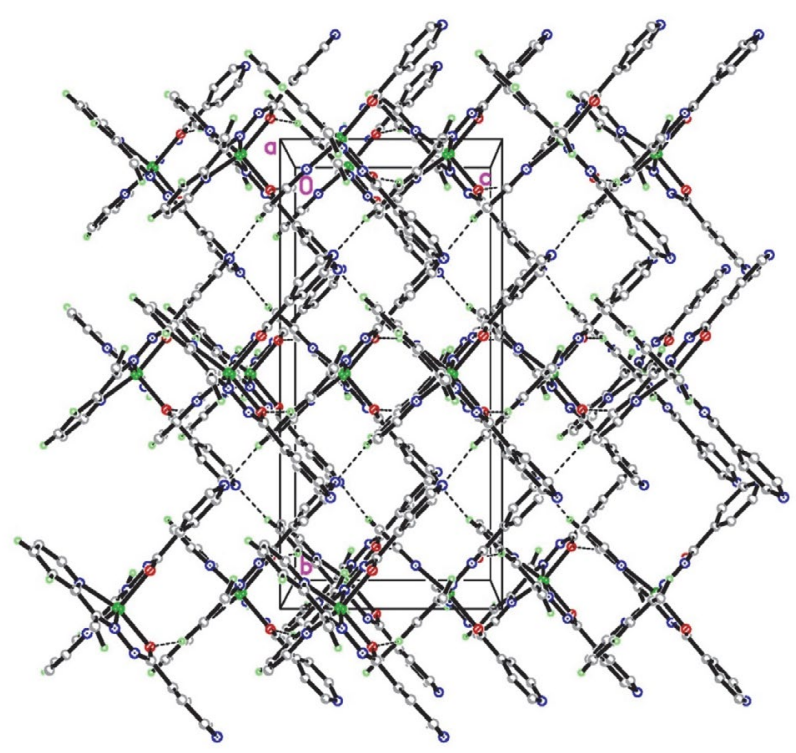

Fig. 2. Molecular packing structure of complex 1, with hydrogen bonds drawn as dashed lines.

range from $74.22(13)$ to $109.70(15)^{\circ}$ and from $148.77(11)$ to $173.3(3)^{\circ}$, respectively, indicating the distortion of the octahedral coordination from ideal geometry. In the crystal structure of the compound, the complex molecules are linked through hydrogen bonds (Table 3), to form a three-dimensional network (Fig. 2).

\section{4. Structure Description of Compound 2}

The molecular structure of compound $\mathbf{2}$ is shown in Fig. 3. Selected bond distances and angles are listed in Table 2 . The compound contains a $[\mathrm{MnL}(\mathrm{HL})]^{+}$complex cation and a perchlorate anion. The $\mathrm{Mn}$ atom in the [Mn$\mathrm{L}(\mathrm{HL})]^{+}$complex cation is coordinated by two pyridine $\mathrm{N}$, two imine $\mathrm{N}$, and two enolate $\mathrm{O}$ atoms from one deprotonated form of the hydrazone ligand and one zwitterionic form of the hydrazone ligand, forming an octahedral geometry. The hydrazones act as tridentate ligands, forming two five-membered chelate rings with the $\mathrm{Mn}$ atom. The bond distances subtended at the $\mathrm{Mn}$ atom are comparable to those observed in the similar manganese(II) complexes with Schiff bases. ${ }^{15}$ The cis and trans coordinate bond angles are range from $70.38(15)$ to $125.52(15)^{\circ}$ and from $141.99(14)$ to $155.58(17)^{\circ}$, respectively, indicating the distortion of the octahedral coordination from ideal geometry. In the crystal structure of the compound, the $[\mathrm{MnL}(\mathrm{HL})]^{+}$complex cations and the perchlorate anions are linked through hydrogen bonds (Table 3), to form a three-dimensional network (Fig. 4).

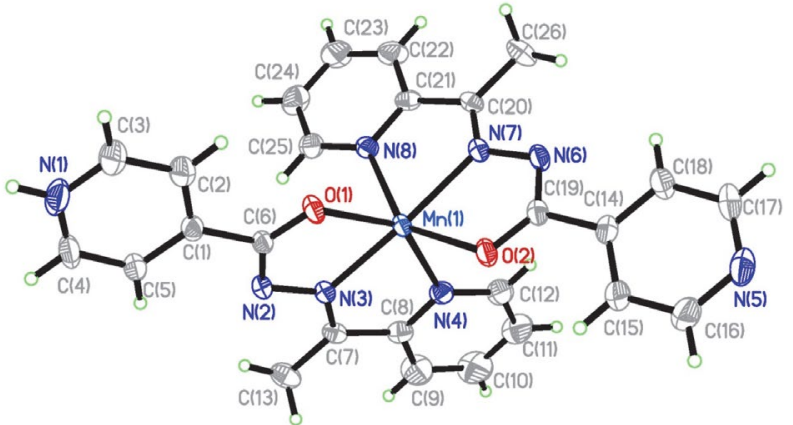

Fig. 3. Perspective view of complex $\mathbf{2}$ with $30 \%$ probability thermal ellipsoids.

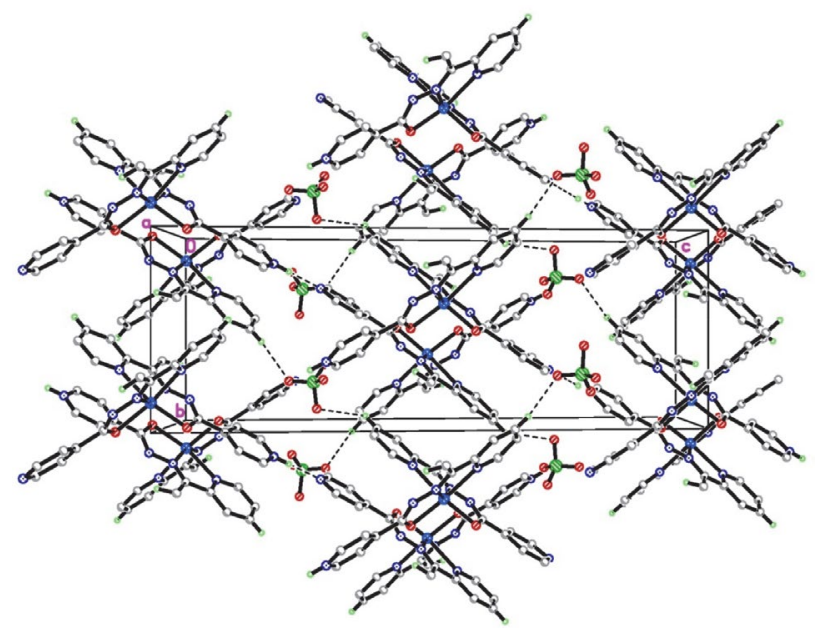

Fig. 4. Molecular packing structure of complex 2, with hydrogen bonds drawn as dashed lines.

\section{5. Antimicrobial Activity}

The results are summarized in Table 4. A comparative study of minimum inhibitory concentration (MIC) values of the hydrazone and the metal complexes indicates that the complexes have better activity than the free hy- 
drazone. Generally, this is caused by the greater lipophilic nature of the complexes than the ligand. Such increased activity of the metal chelates can be explained on the basis of chelating theory. ${ }^{16}$ On chelating, the polarity of the metal atoms will be reduced to a greater extent due to the overlap of the ligand orbital and partial sharing of positive charge of the metal atoms with donor atoms. Further, it increases the delocalization of $p$-electrons over the whole chelate ring and enhances the lipophilicity of the complexes. This increased lipophilicity enhances the penetration of the complexes into lipid membrane and blocks the metal binding sites on enzymes of microorganisms.

From Table 4, it is obvious that the two complexes have higher antibacterial and antifungi activities against Staphylococcus aureus, Escherichia coli, and Candida albicans when compared to the free hydrazone. Complex $\mathbf{1}$ has strong activity against Escherichia coli, with MIC value of $0.20 \mu \mathrm{g} / \mathrm{mL}$, which is comparable to Tetracycline. Complex 1 has medium activity against Staphylococcus aureus and weak activity against Candida albicans. Complex 2 has effective activity against Escherichia coli, and weak activity against Staphylococcus aureus and Candida albicans. In general, the zinc complex has stronger activity against Staphylococcus aureus, Escherichia coli, and Candida albicans than the manganese complex. So, the metal type of the complexes can influence the antimicrobial activity.

Table 4. MIC values $(\mu \mathrm{g} / \mathrm{mL})$ for the antimicrobial activities of the tested compounds

\begin{tabular}{lccc}
\hline Compounds & $\begin{array}{c}\text { Staphylococcus } \\
\text { aureus }\end{array}$ & $\begin{array}{c}\text { Escherichia } \\
\text { coli }\end{array}$ & $\begin{array}{c}\text { Candida } \\
\text { albicans }\end{array}$ \\
\hline The hydrazone & 64 & 32 & $>512$ \\
$\mathbf{1}$ & 8.0 & 2.0 & 64 \\
$\mathbf{2}$ & 16.0 & 8.0 & 128 \\
Tetracycline & 0.32 & 2.12 & $>1024$ \\
\hline
\end{tabular}

\section{Supplementary Mateiral}

CCDC 1871743 for $\mathbf{1}$, and 1871744 for $\mathbf{2}$ contain the supplementary crystallographic data for this paper. These data can be obtained free of charge at http://www.ccdc. cam.ac.uk/const/retrieving.html or from the Cambridge Crystallographic Data Centre, 12 Union Road, Cambridge CB2 1EZ, UK; fax: +44(0)1223-336033 or email: deposit@ ccdc.cam.ac.uk.

\section{Acknowledgments}

This research was supported by the Top-class foundation of Pingdingshan University (no. PXY-BSQD-2018006 and PXY-PYJJ-2018002).

\section{References}

1. (a) K. J. Davis, N. M. O. Assadawi, S. Q. T. Pham, M. L. Birrento, C. Richardson, J. L. Beck, A. C. Willis, S. F. Ralph, Dalton Trans. 2018, 47, 13573-13591;

DOI:10.1039/C8DT02727G

(b) S. Banerjee, R. Patra, P. Ghorai, P. Brandao, S. G. Chowdhury, P. Karmakar, A. Saha, New J. Chem. 2018, 42, 1657116582; DOI:10.1039/C8NJ02235F

(c) S. Asadizadeh, M. Amirnasr, F. F. Tirani, A. Mansouri, K. Schenk, Inorg. Chim. Acta 2018, 483, 310-320.

DOI:10.1016/j.ica.2018.08.037

2. (a) Y. Salman, F. B. Barlas, M. Yavuz, K. Kaya, S. Timur, F. C. Telli, Inorg. Chim. Acta 2018, 483, 98-105;

DOI:10.1016/j.ica.2018.08.010

(b) A. S. Burlov, V. G. Vlasenko, Y. V. Koshchienko, N. I. Makarova, A. A. Zubenko, Y. D. Drobin, L. N. Fetisov, A. A. Kolodina, Y. V. Zubavichus, A. L. Trigub, S. I. Levchenkov, D. A. Garnovskii, Polyhedron 2018, 154, 65-76;

DOI:10.1016/j.poly.2018.07.034

(c) S. Alyar, C. H. Sen, H. Alyar, S. Adem, A. Kalkanci, U. O. Ozdemir, J. Mol. Struct. 2018, 1171, 214-222.

DOI:10.1016/j.molstruc.2018.06.004

3. (a) A. K. Ghosh, C. S. Purohit, R. Ghosh, Polyhedron 2018, 155, 194-201; DOI:10.1016/j.poly.2018.08.021

(b) Y.-T. Li, J.-W. Dong, Y. Lu, Y.-T. Gu, C.-N. Shang, F.-Y. Li, Y. Xin, C.-L. Jing, Z.-L. You, Chinese J. Inorg. Chem. 2018, 34, 1192-1198;

(c) L. W. Xue, G. Q. Zhao, Y. J. Han, Y. X. Feng, Russ. J. Coord. Chem. 2011,37, 262-269; DOI:10.1134/S1070328411030110 (d) L. W. Xue, Y. J. Han, G. Q. Zhao, Y. X. Feng, Russ. J. Coord. Chem. 2012, 38, 24-28. DOI:10.1134/S1070328411120104

4. (a) M. Zhang, D.-M. Xian, H.-H. Li, J.-C. Zhang, Z.-L. You, Aust. J. Chem. 2012, 65, 343-350; DOI:10.1071/CH11424

(b) E. W. Ainscough, A. M. Brodie, A. J. Dobbs, J. D. Ranford, J. M. Waters, Inorg. Chim. Acta 1998, 267, 27-38; DOI:10.1016/S0020-1693(97)05548-5

(c) R. N. Patel, S. P. Rawat, M. Choudhary, V. P. Sondhiya, D. K. Patel, K. K. Shukla, D. K. Patel, Y. Singh, R. Pandey, Inorg. Chim. Acta 2012, 392, 283-291.

DOI:10.1016/j.ica.2012.03.040

5. (a) W. Cao, Y.-M. Liu, T. Zhang, J.-P. Jia, Polyhedron 2018, 147, 62-68; DOI:10.1016/j.poly.2018.03.012

(b) A. A. El-Sherif, A. Fetoh, Y. K. Abdulhamed, G. M. Abu El-Reash, Inorg. Chim. Acta 2018, 480, 1-15;

DOI:10.1016/j.ica.2018.04.038

(c) Q.-Y. Mo, J-G. Deng, Y.-N. Liu, G.-D. Huang, Z.-W. Li, P. Yu, Y. Gou, F. Yang, Eur. J. Med. Chem. 2018, 156, 368-380; DOI:10.1016/j.ejmech.2018.07.022

(d) R. Fekri, M. Salehi, A. Asadi, M. Kubicki, Inorg. Chim. Acta 2019, 484, 245-254; DOI:10.1016/j.ica.2018.09.022

(e) Z.-Y. Hao, Q.-W. Liu, J. Xu, L. Jia, S.-B. Li, Chem. Pharm. Bull. 2010, 58, 1306-1312. DOI:10.1248/cpb.58.1306

6. H.-Q. Chang, L. Jia, J. Xu, W.-N. Wu, T.-F. Zhu, R.-H. Chen, T.-L. Ma, Y. Wang, Z.-Q. Xu, Transition Met. Chem. 2015, 40, 485-491. 
7. (a) G.-P. Cheng, L.-W. Xue, C.-X. Zhang, Acta Chim. Slov. 2017, 64, 261-265; DOI:10.17344/acsi.2016.3036

(b) L. Wang, Y.-J. Han, Q.-B. Li, L.-W. Xue, Acta Chim. Slov. 2016, 63, 822-826; DOI:10.17344/acsi.2016.2699

(c) Q.-B. Li, Y.-J. Han, G.-Q. Zhao, L.-W. Xue, Acta Chim. Slov. 2017, 64, 500-505. DOI:10.17344/acsi.2017.3416

8. M. R. Maurya, S. Khurana, W. Zhang, D. Rehder, Dalton Trans. 2002, 3015-3023. DOI:10.1039/b202852m

9. SMART and SAINT. Area Detector Control and Integration Software, Madison (WI, USA): Bruker Analytical X-ray Instruments Inc., 1997.

10. G. M. Sheldrick, SADABS, Program for Empirical Absorption Correction of Area Detector Data, Göttingen (Germany): Univ. of Göttingen, 1997.

11. A. C. T. North, D. C. Phillips, F. S. Mathews, Acta Crystallogr. A 1968, 24, 351-359. DOI:10.1107/S0567739468000707

12. G. M. Sheldrick, SHELXL-97, Program for the Refinement of Crystal Structures, Göttingen (Germany): Univ. of Göttingen, 1997.

13. (a) A. Barry, Procedures and Theoretical Considerations for Testing Antimicrobial Agents in Agar Media, In: Antibiotics in
Laboratory Medicine, Lorian, V. (Ed.), Baltimore: Williams and Wilkins, 1991;

(b) T. Rosu, M. Negoiu, S. Pasculescu, E. Pahontu, D. Poirier, A. Gulea, Eur. J. Med. Chem. 2010, 45, 774-781.

DOI:10.1016/j.ejmech.2009.10.034

14. (a) S. Konar, A. Jana, K. Das, S. Ray, S. Chatterjee, S. K. Kar, Polyhedron 2012, 47, 143-150; DOI:10.1016/j.poly.2012.07.080 (b) Z. He, C. He, Z.-M. Wang, E.-Q. Gao, Y. Liu, C.-H. Yan, Dalton Trans. 2004, 502-504; DOI:10.1039/b315281b

(c) C.-F. Chow, S. Fujii, J.-M. Lehn, Chem. Asian. J. 2008, 3, 1324-1335. DOI:10.1002/asia.200800101

15. (a) C.-F. Wang, Z.-J. Chen, K.-D. Zhao, X.-F. Chen, C.-Y. Zhang, G.-H. Sheng, H.-L. Zhu, J. Coord. Chem. 2016, 69, 2656-2665; DOI:10.1080/00958972.2016.1213819

(b) N. A. Mangalam, S. R. Sheeja, M. R. P. Kurup, Polyhedron 2010, 29, 3318-3323; DOI:10.1016/j.poly.2010.09.007

(c) S. Banerjee, A. Ray, S. Sen, S. Mitra, D. L. Hughes, R. J. Butcher, S. R. Batten, D. R. Turner, Inorg. Chim. Acta 2008, 361, 2692-2700. DOI:10.1016/j.ica.2008.01.019

16. J. W. Searl, R. C. Smith, S. Wyard, J. Proc. Phys. Soc. 1961, 78, 1174-1181. DOI:10.1088/0370-1328/78/6/311

\section{Povzetek}

Sintetizirali smo dve enojedrni cinkovi(II) in manganovi(II) spojini, $\left[\mathrm{ZnL}_{2}\right]$ (1) in $[\mathrm{MnL}(\mathrm{HL})] \mathrm{ClO}_{4}(2)$, kjer je $\mathrm{L}$ monoanionska oblika $N^{\prime}$-(1-(piridin-2-il)etiliden)izonikotinohidrazida (HL) in HL ion dvojček HL, ter ju okarakterizirali z elementno analizo, IR in UV-Vis spektroskopijo ter monokristalno rentgensko strukturno analizo. Spojina 1 je nevtralen $\left[\mathrm{ZnL}_{2}\right]$ kompleks. Spojina 2 je zgrajena iz $[\mathrm{MnL}(\mathrm{HL})]^{+}$kompleksnega iona in enega perkloratnega aniona. Kovinski ioni v obeh kompleksih so oktaedrično koordinirani. Hidrazonski ligand se koordinira na kovinski ion preko piridinskega $\mathrm{N}$, iminskega $\mathrm{N}$ in enolatnega $\mathrm{O}$ atoma. Spojinama smo določili antimikrobno aktivnost proti Staphylococcus aureus, Escherichii coli in Candidi albicans. 